
студентов профессионально-ориентированному английскому языку на неязыковых фракультетах в вузе (специальность «Экология»)

Костарева Е.А.

ФГБОУ ВО «Пермский государственный национальный исследовательский университет»,

Пермь, Российская Федерация.

(D) ORCID: https://orcid.org/0000-0002-9412-8413, e-mail: kostareva8419@mail.ru

Резюме: В статье затрагиваются актуальные вопросы организации внеаудиторной самостоятельной работы студентов при обучении английскому языку на неязыковых специальностях в вузе и ее влияние на интенсивность процесса обучения. Рассматриваются методические основы интенсификации внеаудиторной самостоятельной работы студентов. Цель статьи - рассмотрение актуального вопроса, вызванного необходимостью применять в современном образовании такие новые формы организации самостоятельной работы студентов, которые могут быть эффективными и способствовать повышению учебной мотивации и активной познавательной деятельности студентов. В статье предлагается соединять устоявшиеся, структурированные темы с дискуссионными актуальными вопросами при обучении студентов профессионально-ориентированному английскому и учитывать этот принцип при разработке учебных материалов по самостоятельной работе студентов и включать их в отдельный раздел при написании учебных или учебно-методических пособий. В ходе исследования были применены следующие методы: анализ, наблюдение, сравнение. Результаты исследования. Было выявлено, что создание и использование практико-ориентированных учебных материалов предполагают большую индивидуализацию заданий, большую свободу исследовательского поиска, ориентацию на фрормирование профессиональных компетенций, увеличение творческой активности обучающихся. Делается вывод о том, что практико-ориентированный подход к организации самостоятельной работы студентов при обучении английскому языку может быть одним из способов совершенствования практических языковых умений и стимулом для формирования личностных качеств самого студента.

Ключевые слова: познавательная деятельность, практико-ориентированный подход, самостоятельная работа студентов, эффективность самостоятельной работы, организация учебных действий.

Для цитирования: Костарева Е.А. Внеаудиторная самостоятельная работа как средство интенсификации процесса обучения студентов профессионально-ориентированному английскому языку на неязыковых фракультетах в вузе (специальность «Экология») // Развитие образования. - 2020. - № 1 (7). - C. 51-54. DOI:10.31483/r-74735.

\title{
Extracurricular Self-Guided Work As a Means of Intensifying the Process of Teaching Professionally- Oriented English to Students of Non-Linguistic Specialties at the University (Specialty "Ecology")
}

Elena A. Kostareva

FSBEI of HE "Perm State National Research University", Perm, Russian Federation.

DORCID: https://orcid.org/0000-0002-9412-8413, e-mail: kostareva8419@mail.ru

\begin{abstract}
The article touches upon some actual issues on the organization of extracurricular students' self-guided work in teaching English at non-linguistic specialties at the university and its impact on the learning process intensity. The article discusses the methodological foundations of the intensification of extracurricular students' self-guided work. The purpose of the article is to consider the current issue caused by the need to apply in modern education such new forms of organization of students' self-guided work that can be effective and contribute to increase of students' educational motivation and active cognitive activity. It is proposed to combine established, structured topics with controversial topical issues in teaching professionally-oriented English to students and take this principle into account when developing educational materials for extracurricular students' self-guided work and include them in a separate section when writing textbooks or teaching aids. During the study the following methods were applied: analysis, observation, comparison. Research result. It was found out that creation and application of practically-oriented teaching materials require greater individualization of tasks, greater freedom of research, orientation toward the professional competencies formation, and an increase in students' creative activity. It is concluded that practically-oriented approach in the organization of students' self-guided work in teaching English can be one of the ways to improve practical language skills and an incentive for students' personal qualities formation.

Keywords: cognitive activity, extracurricular self-guided work efficiency, practically-oriented approach, organization of educational activities, extracurricular students' self-guided work.

For citation: Elena A. Kostareva (2020). Extracurricular Self-Guided Work As a Means of Intensifying the Process of Teaching Professionally-Oriented English to Students of Non-Linguistic Specialties at the University (Specialty "Ecology"). Razvitie obrazovaniya = Development of education, 1(7), 51-54. (In Russ.) DOI:10.31483/r-74735.
\end{abstract}


Аудитори тулашӗнче харпӑр хай тӗллӗн ӗс̧лени - вузӑн чӗлхе факультетӗнче ( Экологи» специальность) вёренмен студентсене профессипе сыыхӑнман акӑлчан чӗлхине тухӑс̧лӑ вӗрентмелли хатӗр

Костарева Е.А.

AВ ФПБ «Пермь патшалӑх наци тӗпчев институчӗ» ВУ, Пермь, Рас̧с̧ей Патшалӑхе̌.

(D) ORCID: https://orcid.org/0000-0002-9412-8413, e-mail: kostareva8419@mail.ru

\begin{abstract}
Аннотаци: Статьяра студентсене аслӑ шкулӑн чӗлхепе с̧ыхӑнман специальнос̧не алла илекен студентсене акӑлчан чӗлхи вӗрентнӗ май аудитори тулашӗнче ку е вӑл ӗс̧е мӗнле йӗркелемелли с̧ивӗч ыйтусене тата ку ӗс̧ вӗренӳ тухӑс̧лӑхне епле ӳстернине пӑхса тухнӑ. Аудитори тулашӗнчи ӗс̧е вӑйлатма май паракан меслет никӗсне ус̧ӑмлатнӑ. Статья тӗллевӗ - хальхи вӗренӳре студентсене хӑйсем тӗллӗн вӗренме тата нумай пӗлме хавхалантаракан с̧ӗнӗ формӑсемпе усӑ курас тивӗс̧е ӑнлантарасси. Статья авторӗ тытӑма кӗрсе с̧ирӗпленнӗ темӑсемпе паян куншӑн тавлашуллӑ та пӗлтерӗшлӗ темӑсене пӗрлештерме, ку принципа кашни харпӑр хӑй тӗллӗн вӗренме кирлӗ материла хатӗрленӗ май шута илме, вӗренӱ кӗнекисенче тата вӗренӳпе меслет хатӗрӗсенче ятарлӑ пай уйӑрса унта вырнас̧тарма сӗнет. Тепченӗ май с̧ак меслетсемпе усӑ курнӑ: тишкерӱ, сӑнав, танлаштару. Тӗпчев пӗтӗмлетецвӗсем. Акӑ мӗн тупса палӑртнӑ: вӗренӳ материалне практикӑпа с̧ыхӑнтарса хатӗрлес пулсан ӗс̧сене кашни валли тумалла, студентсен професси компетенцине йӗркелессине тӗпе хумалла, вӗренекенсен творчествӑллӑ активлӑхне шута илмелле. Петтеммлету́ре каланӑ тӑрӑх, акӑлчан чӗлхине вӗренекен студентсен хӑйсем тӗллӗн тӑвакан ӗс̧не йӗркеленӗ чух специальнос̧а шута илни студентсен акӑлчанла калас̧ӑвне пурнӑс̧ра кирлӗ пек лайӑхлатма, кашнин с̧ынлӑх пахалӑхне ӱстерме май паракан вӑй пулса тӑрать.
\end{abstract}

Tӗп сӑмахсем: пӗлў е̌с̧ӗ, ориентланӑ меслет, студентсен хӑйсен тӗллӗн тунӑ ӗс̧ӗ, хӑй тӗллӗн ӗс̧ тухӑс̧лӑхӗ, вӗренў ӗс̧ӗсене йӗркелесси.

Цитатӑлама: Костарева Е.А. Аудитори тулашӗнче харпӑр хай тӗллӗн ӗс̧лени - вузӑн чӗлхе факультетӗнче («экологи» специальность) вӗренмен студентсене профессипе с̧ыхӑнман акӑлчан чӗлхине тухӑс̧лӑ вӗрентмелли хатӗр // Вӗренў аталанӑвӗ. - 2020. - № 1 (7). - C. 51-54. DOI:10.31483/r-74735.

\section{Введение}

амостоятельная работа студентов при обучении иностранному языку в вузе носит многофункциональный характер и в целом помогает овладеть иностранным языком как необходимой профессиональной составляющей современного специалиста, способствует формированию навыков самостоятельного приобретения знаний и развитию информационной культуры. Значение самостоятельной работы определяется целями современного образования и требованиями, которые диктует жизнь, а именно: постоянное совершенствование личности [4].

Традиционно основной целью организации самостоятельной работы студентов при обучении их английскому языку в неязыковом вузе является формирование умения самостоятельно читать оригинальную литературу по специальности с целью извлечения профессионально-ориентированной информации. Исходя из понимания, что обучение чтению подразумевает умение работать с литературой, которое является базовым умением при осуществлении любой профессиональной деятельности, можно утверждать, что этот вид учебной деятельности очень важен. С точки зрения И.С. Ипатовой, самостоятельная работа по повышению уровня владения иностранным языком чаще всего связана с чтением, которое способно превращать обучающихся «из пассивного слушателя в «источник» идей и действий, что дает им возможность мыслить активно» [1].

Однако, в реальности традиционные формы организации самостоятельной работы студентов ориентированы на репродуктивный тип, при котором осуществляется воспроизводство определенного продукта языковой деятельности (переведенный текст на русский или английский язык) по заданию преподавателя и может быть важным и эффективным для определенных задач обучения. В тоже время такие формы самостоятельной работы могут носить формальный и бессистемный характер, что не может способствовать повышению учебной мотивации и активной познавательной деятельности студентов.

Постановка проблемы. Проблема понимания «самостоятельной работы студента» как «рода деятельности, который включает в себя поиск источников познания, средств осуществления и результаты познавательной деятельности, проводимой без прямой помощи преподавателя» особо актуальна для современного образовательного процесса.

Как подчеркивает А.Р. Лаврентьев: «Учебный материал, передаваемый на самостоятельное изучение, должен быть связан либо с темами устоявшимися, четко структурированными, либо, напротив, должен затрагивать вопросы дискуссионные, обусловленные новейшими веяниями в жизни общества, по актуальным проблемам» [3]. Отметим, что при обучении профессионально-ориентированному английскому языку устоявшиеся, структурированные темы, можно органично соединять с дискуссионными актуальными вопросами, поскольку круг этих вопросов профессионально детерминирован и знаком студенту. Этим принципом следует руководствоваться при разработке учебных материалов по самостоятельной работе студентов, изучающих иностранный язык в вузе и включать их в отдельный раздел при написании современных учебных 
или учебно-методических пособий. Учебное пособие «Английский язык. Экология», которое было создано преподавателями кафедры английского языка профессиональной коммуникации ПГНИУ, содержит главу по самостоятельной работе студентов «Еxtracurricular Self-Guided Students Work» [2]. Тематически учебник представлен не только текстами для чтения по экологии, но содержит творческие задания практической направленности, выполнение которых потребует от студентов, кроме прочтения текста, разнообразных умений, направленных на развитие и совершенствование их познавательной деятельности. Многие задания предполагают совместную деятельность учащихся, что развивает их умение работать в команде. В качестве примеров приведем формулировки некоторых заданий к учебным текстовым материалам по экологическим темам. Студентам-экологам они хорошо знакомы, при этом им приходится заниматься поисковой деятельностью с привлечением Интернет-ресурсов, проектной деятельностью, групповой работой, учиться работать со словарями, делать коллажи и туристическую карту национального парка в Англии, а также рисовать, лепить и даже готовить тесто.

1. Work in groups of 3-4 students. Discuss the contents of the article to create a collage depicting the beauty of nature at Shotover in different seasons.

2. Work in groups of 3-4 students. Discuss the contents of the article to draw a guide map depicting the three main trails at Shotover Country Park: red, yellow and green.

Задание, для выполнения которого нужно приготовить тесто по рецепту:

Make basic bread dough in the following way:

1. Mix about $0.5 \mathrm{~g}$ of sugar into about $50 \mathrm{~cm} 3$ of warm water.

2. Mix about $1 \mathrm{~g}$ of dried yeast into the warm sugar solution, and leave for a few minutes.

3. Measure out about $75 \mathrm{~g}$ of flour.

4. Add the yeast and sugar mixture to the flour, and pull it around with your hands to make dough.

5 . Leave the dough to rise in a warm place covered with cling film.

Study the factors which affect how much the dough rises and also how fast it rises. Choose two factors from the following list to investigate: temperature, addition of salt, addition of flour improvers, such as ascorbic acid, addition of amylase.

Prepare a two-minute report on the results of your investigation on making dough. Get ready to speak about it before the group [2].

Для выполнения таких заданий студенту потребуется не просто подготовить чтение и перевод текста, но найти необходимую дополнительную информацию самостоятельно и осуществить определенный набор действий, указанный в задании. Текст, по сути, является лексической и грамматической основой для осуществления самостоятельной работы студента по иностранному языку и не является предметом проверки со стороны преподавателя.
Mетоды исследования. За счет применения практико-ориентированных учебных материалов такой подход к организации самостоятельной работы студентов предполагает большую индивидуализацию заданий, большую свободу исследовательского поиска, ориентацию на формирование профессиональных компетенций, увеличение творческой активности обучающихся [6]. Кроме того, благодаря практико-ориентированному подходу самостоятельная работа студентов при обучении английскому языку может быть одним из способов совершенствования практических языковых умений и стимулом для формирования личностных качеств самого студента: целеустремлённость в работе; инициативность, более высокая организованность при выполнении поставленных задач. Современному студенту необходимы знания, умения и навыки, которые не утратятся со временем и не отложатся в пассивный запас. Для этого в современном образовательном процессе преподаватель должен использовать такие технологии, которые учат самостоятельно мыслить и достигать поставленных целей [5]. Технологию развития критического мышления можно успешно использовать в различных видах учебной деятельности, так как она включает в себя большое количество разнообразных приёмов, позволяет студенту ориентироваться в объёме предлагаемого материала, учит критически относиться к получаемой информации, самостоятельно использовать приёмы во внеаудиторной деятельности [4].

Результаты исследования. Контроль внеаудиторной самостоятельной работы необходимо проводить регулярно. Выполненные задания студент может отправлять преподавателю на электронную почту, а проверку выполнения заданий с коммуникативной направленностью следует осуществлять в присутствии всей группы во время аудиторного занятия, чтобы студент имел возможность продемонстрировать усвоенный устный материал, показать свое умение участвовать в диалоге или дискуссии, а также сделать доклад или презентацию. Результаты внеаудиторной самостоятельной работы как составной части учебной деятельности студента можно выносить на текущий и итоговый контроль.

В заключение хотелось бы подчеркнуть, что регулярно проводимая внеаудиторная самостоятельная работа повышает общий уровень владения иностранным языком и может положительно отражаться на эффективности процесса обучения, развивать у студентов коммуникативные навыки и умения межличностного, профессионального общения. Самостоятельная работа студентов по иностранному языку в неязыковом вузе, являясь сегодня одним из обязательных требований к организации образовательного процесса, призвана способствовать развитию творческого потенциала личности студента и формированию навыков самоорганизации и самообразования, что и обеспечивает ему непрерывный личностный и профессиональный рост. 


\section{Список литературы}

1. Ипатова И.С. Культура речи и Языковая Мода: Проблема Коммуникативных Допусков // Различия. Неравенства и социологическое воображение: материалы Первой конференции Европейской Социологической Ассоциации (Прага, 2015). - Прага, 2015.

2. Кочкарева И.В. Английский язык. Экология: учеб. пособие / И.В. Кочкарева, Е.А. Костарева. - Пермь, 2019. - 133 c.

3. Лаврентьев А.Р. Формы самостоятельной работы студентов юридических вузов // Юридическое образование и науки. - 2003. - №1. - С. 37-41.

4. Назаренко Т.Ю. Самостоятельная работа студентов на занятиях иностранного языка в вузе // Современные научные исследования и инновации. - 2016. - №4 [Электронный pecypc]. - Режим доступа: http://web.snauka.ru/ issues/2016/04/66251 (дата обращения: 25.03.2019).

5. Путиловская Т.С. Психолого-дидактические принципы организации самостоятельной работы студентов при обучении иностранному языку // Преподавание иностранных языков и литератур в неязыковых вузах: материалы межвузовской конференции (Москва, 17 апреля 2007г.). - М.: Изд-во МГЭИ, 2007. - С. $23-29$.

6. Храмова Ю.Н. Организация внеаудиторной самостоятельной работы по иностранному языку для студентов-юристов в неязыковом вузе / Ю.Н. Храмова, Р.Д. Хайруллин // Современные наукоемкие технологии. - 2016. №5 [Электронный ресурс]. - Режим доступа: http://top-technologies.ru/ru/article/view?id=35885 (дата обращения: 23.12.2019).

\section{References}

1. Ipatova, I. S. (2015). Kul'tura rechi i Iazykovaia Moda: Problema Kommunikativnykh Dopuskov. Razlichiia. Neravenstva i sotsiologicheskoe voobrazhenie. Praga.

2. Kochkareva, I. V., \& Kostareva, E. A. (2019). Angliiskii iazyk. Ekologiia: ucheb. posobie., 133. Perm'.

3. Lavrent'ev, A. R. (2003). Formy samostoiatel'noi raboty studentov iuridicheskikh vuzov. Iuridicheskoe obrazovanie i nauki, 1, 37-41.

4. Nazarenko, T. Iu. (2016). Samostoiatel'naia rabota studentov na zaniatiiakh inostrannogo iazyka v vuze. Sovremennye nauchnye issledovaniia i innovatsii, 4. Retrieved from http://web.snauka.ru/issues/2016/04/66251

5. Putilovskaia, T. S. (2007). Psikhologo-didakticheskie printsipy organizatsii samostoiatel'noi raboty studentov pri obuchenii inostrannomu iazyku. Prepodavanie inostrannykh iazykov i literatur v neiazykovykh vuzakh, 23-29. M.: Izd-vo MGEI.

6. Khramova, Iu. N., \& Khairullin, R. D. (2016). Organizatsiia vneauditornoi samostoiatel'noi raboty po inostrannomu iazyku dlia studentov-iuristov v neiazykovom vuze. Sovremennye naukoemkie tekhnologii, 5. Retrieved from http://toptechnologies.ru/ru/article/view?id=35885

\begin{tabular}{|c|c|c|}
\hline $\begin{array}{l}\text { Информация об авторе } \\
\text { Костарева Елена Александровна - } \\
\text { магистр, старший преподаватель } \\
\text { кафедры английского языка } \\
\text { профессиональной коммуникации } \\
\text { ФГБОУ ВО «Пермский государ- } \\
\text { ственный национальный исследо- } \\
\text { вательский университет», Пермь, }\end{array}$ & $\begin{array}{l}\text { Information about the author } \\
\text { Elena A. Kostareva - master, senior } \\
\text { lecturer at the Department of the } \\
\text { English Language of Professional } \\
\text { Communication at the FSBEI of } \\
\text { HE "Perm State National Research } \\
\text { University", Perm, Russian } \\
\text { Federation. }\end{array}$ & $\begin{array}{l}\text { филологи ӑслӑлӑхӗн магистрӗ, } \\
\text { АВ ФПБ «Пермь патшалӑх наци } \\
\text { тӗпчев институчӗ» ВУн професси } \\
\text { хутшӑнӑвӗн акӑлчан чӗлхи } \\
\text { кафедрин аслӑ преподавателӗ, } \\
\text { Рас̧сей, Пермь. }\end{array}$ \\
\hline
\end{tabular}

Российская Федерация 